\title{
Perkembangan regulasi perbankan syariah di Indonesia
}

\author{
Sofyan Al-Hakim \\ Faultas Syariah dan Hukum UIN Sunan Gunung Djati Bandung \\ Email:sofyan.alhakim@yahoo.co.id
}

Not only Islamic financial institutions rate impressively, but also Islamic banking. Statistics released by Bank Indonesia prove the premise. At the same time, supporting the legality of Islamic banking operations became more solid. Although at the beginning of its establishment faced legal problems, but since the enactment the Islamic Banking No. 21 of 2008 has been issued, the problem is resolved. Authority that important in the dynamics of Islamic banking regulation is the National Sharia BoardCouncil of Ulama Indonesia (DSN-MUI). The council became the source of authoritative institutions in guarding the observance of the Islamic banking industry to comply with the rules of sharia. All Islamic banking products must be controlled under sharia compliance by the DSN-MUI. Then, the fatwa is absorbed by Bank Indonesia and Bank Indonesia Regulation (Peraturan Bank Indonesia) is set to be. In this context, the national banking regulator has a significant association with DSN-MUI fatwa.

Tidak hanya lembaga keuangan syariah saja yang melaju dengan impresif, perbankan syariah pun melaju dengan impresif pula. Angka statistik yang dirilis Bank Indonesia membuktikan premis tersebut. Pada waktu yang bersamaan, legalitas yang menopang operasional perbankan syariah pun semakin kokoh. Walaupun diawal pendiriannya menghadapi masalah legalitas, namun sejak ditetapkannya UU no 21 tahun 2008 tentang Perbankan Syariah maka masalah legalitas relatif sudah teratasi. Otoritas yang penting dalam dinamika regulasi perbankan syariah adalah Dewan Syariah Nasional-Majelis Ulama Indonesia (DSN-MUI). Lembaga ini menjadi sumber otoritatif dalam mengawal ketaatan pelaku industri perbankan syariah untuk mematuhi aturan syara. Semua produk perbankan syariah harus difatwakan sesuai syariah oleh DSN-MUI. Fatwa ini kemudian diserap oleh Bank Indonesia dan ditetapkan menjadi Peraturan Bank Indonesia. Dalam konteks ini maka regulasi perbankan nasional memiliki keterkaitan yang signifikan dengan fatwa DSN-MUI.

Keywords: Islamic Banking; Fatwa; National Sharia Board; Regulation 
ljtihad, Jurnal Wacana Hukum Islam dan Kemanusiaan, Volume 13, No. 1, Juni 2013: 15-32

\section{Pendahuluan}

Harapan sebagai umat Islam untuk dapat bermuamalah keuangan dengan syar'i telah terwujud. Secara formal pendirian Bank Muamalat Indonesia yang diprakarsai tokoh-tokoh MUI pada tahun 1991 telah membuka lembaran baru sistem perbankan di Indoensia (Adams, 2000:289-291). Perkembangan lembaga keuangan syariah di Indonesia tidak dapat dipandang sebelah mata. Berdasarkan laporan Global Islamic Finance Report 2011 yang diterbitkan di London telah disusun Islamic Finance Country Index. Menurut Indeks ini, Indonesia menempati peringkat pertama negara-negara non Islam dan peringkat keempat dari seluruh Negara dalam perkembangan keuangan syariah. Enam besar negara itu adalah Iran, Malaysia, Saudi Arabia, Indonesia, Bahrain dan Inggris. Posisi ini menempatkan dua negara Indonesia dan Malaysia berada pada posisi strategis lembaga keuangan syariah dunia (Karim, 2012).

Menurut Muhammad (2000:62), perkembangan lembaga keuangan syariah (LKS) khususnya perbankan syariah di Indonesia, pada dua dekade ini digambarkan melaju secara impresif. (www.bi.go.id). Fakta ini berbeda dengan tesis dari Mohammed Arif (1996: 305306) yang menyatakan bahwa perbankan syariah sulit berkembang di Indonesia karena alasan politik sekular yang di jalan orde baru. Namun, ketika regim orde baru tumbang oleh reformasi yang digawangi oleh mahasiswa maka tesis itu pun runtuh dengan sendirinya. Hal ini diawali dengan berdirinya Bank Muamalah Indonesia pada tahun 1991, sampai bulan September 2012 telah berdiri 11 bank umum syariah, 24 unit usaha syariah, dan 156 BPRS. Keseluruhan unit dilayani di 2.536 kantor. Pertumbuhan LKS ditopang oleh perkembangan perbankan syariah yang dikenal dengan iB (Islamic Bank). Sejak mulai dikembangkannya sistem perbankan syariah di Indonesia, dalam kurun waktu 20 tahun total aset industri perbankan syariah telah meningkat sebesar 39 kali lipat dari Rp 1,79 triliun pada tahun 2000, menjadi Rp 70,146 triliun pada akhir tahun 2010. Laju pertumbuhan aset secara impresif tercatat $46,3 \%$ per tahun, dengan rata-rata pertumbuhan dalam 5 tahun terakhir. Untuk periode 2009 sd 2010 yang lalu, pertumbuhan yang mencapai rata-rata 36,2\% pertahun bahkan lebih tinggi daripada laju pertumbuhan aset perbankan syariah regional (Asia Tenggara) yang hanya berkisar 30\% per tahun untuk periode yang sama (Statistik BI Bulan April 2012).

Sejak diterbitkannya Undang-Undang (UU) No. 21 Tahun 2008 tentang Perbankan Syariah sebagai landasan legal formal yang secara khusus mengatur berbagai hal mengenai perbankan 
syariah di tanah air, maka kecepatan pertumbuhan industri ini diperkirakan akan melaju lebih kencang lagi. Hal ini terlihat dari indikator penyaluran pembiayaan yang mencapai ratarata pertumbuhan sebesar 36,7\% per tahun dan indikator penghimpunan dana dengan ratarata pertumbuhan mencapai 33,5\% per tahun untuk tahun 2007 sampai dengan tahun 2010. Angka-angka pertumbuhan yang impresif tersebut tidak hanya berhenti di atas kertas sebagai perputaran uang di sektor finansial. iB Perbankan syariah membuktikan dirinya sebagai sistem perbankan yang mendorong sektor riil, seperti diindikasikan oleh rasio pembiayaan terhadap penghimpunan dana (Financing to Deposit ratio, FDR) yang rata-rata mencapai 90\% pada dua tahun terakhir.

Berdasarkan catatan BI per November 2011, pembiayaan yang disalurkan bank syariah meningkat Rp 31,87 triliun atau 45,37\% dibanding periode yang sama tahun 2010. Pembiayaan itu menjadi Rp 102,11 triliun dari 70,24 triliun. Pembiayaan bermasalah pun membaik dari 3,12\% ke 2,85\%. Dana pihak ketiga bank syariah mencapai Rp 107,36 triliun dari Rp 77,64 triliun atau naik 38,28\%. Rasio pembiayaan terhadap dana pihak ketiga telah mencapai 95,11\%, naik dari periode sebelumnya sebesar 90,47\%. Dengan kinerja tersebut, aset bank syariah mencapai Rp 135,9 triliun atau meningkat 35,55\% dari periode sebelumnya sebesar Rp 100,26 triliun. Dengan demikian, pangsa pasar bank syariah mencapai 3,9\%.

Sejalan dengan kinerja bank umum yang positif, selama Semester I-2012, Perbankan Syariah yang terdiri dari Bank Umum Syariah (BUS), Unit Usaha Syariah (UUS) dan Bank Pembiayaan Rakyat Syariah (BPRS) juga menunjukkan kinerja dengan tren pertumbuhan yang positif. Hal tersebut tercermin dari total aset yang meningkat, disertai pertumbuhan pada permodalan, profitabilitas, fungsi intermediasi, efisiensi, kualitas pembiayaan dengan likuiditas yang tetap terjaga. Secara komposisi, pada semester ini pangsa BUS+UUS sebesar 97,43\% masih mendominasi aset Perbankan Syariah. Besaran pangsa ini meningkat dibandingkan posisi yang sama tahun sebelumnya sebesar 97,27\%.

Total aset BUS dan UUS pada Semester I-2012 mencapai Rp155,41 triliun, meningkat dibanding posisi Semester II-2011 sebesar Rp 145,47 triliun dan Semester I-2011 sebesar Rp 109,75 triliun. Dengan perkembangan tersebut, total aset Perbankan Syariah mencapai $\pm 3,99 \%$ dari total aset industri perbankan nasional. 
ljtihad, Jurnal Wacana Hukum Islam dan Kemanusiaan, Volume 13, No. 1, Juni 2013: 15-32

Pada sisi lembaga keuangan non bank, Badan Pengawas Pasar Modal dan Lembaga Keuangan (Bapepam dan LK) telah menetapkan 229 perusahaan publik yang telah terdaftar di bursa efek Jakarta sebagai perusahaan dengan kualifikasi syariah. Demikian juga dengan asuransi syariah yang pada tahun 1994 hanya terdiri dari dua perusahaan sampai tahun 2006 telah berdiri 34 lembaga asuransi syariah. Dari data di atas nampak sekali bahwa lembaga keuangan syariah berkembang cukup progresif. Namun apakah progresifitas tersebut sudah dibarengi dengan kepastian regulasi dan apakah regulasi yang ada sudah sesuai dengan ketentuan syariah?

\section{Perkembangan regulasi perbankan syariah}

Perbankan syariah merupakan bidang kegiatan ekonomi syariah pertama yang berkembang luas di Indonesia pada awal abad 20. Meskipun pada awalnya kegiatan perbankan syariah ini hanya dilakukan oleh satu perusahaan perbankan, yaitu Bank Muamalat Indonesia yang melakukan kegiatan perbankan dengan prinsip syariah secara menyeluruh, kegiatan perbankan syariah kemudian diikuti dengan pendirian Bank Umum Syariah (BUS) lainnya, pembentukan Unit Usaha Syariah (UUS) oleh bank-bank konvensional, dan pendirian Bank Pembiayaan Rakyat Syariah (BPRS) (Barlinti, 2010:224).

Pengaturan kegiatan perbankan syariah pertama kali diatur dalam UU No. 7 Tahun 1992 tentang Perbankan, dengan menyebut istilah "bank berdasarkan prinsip bagi hasil", tanpa memberikan definisi prinsip bagi hasil tersebut. Definisi prinsip bagi hasil disebutkan dalam PP No. 72 Tahun 1992 tentang Bank Berdasarkan Prinsip Bagi Hasil Pasal 2 yaitu prinsip bagi hasil berdasarkan Syari'at yang digunakan oleh bank berdasarkan prinsip bagi hasil dalam: (a) menetapkan imbalan yang akan diberikan kepada masyarakat sehubungan dengan penggunaan/ pemanfaatan dana masyarakat yang dipercayakan kepadanya; (b) menetapkan imbalan yang akan diterima sehubungan dengan penyediaan dana kepada masyarakat dalam bentuk pembiayaan baik untuk keperluan investasi maupun modal kerja termasuk kegiatan usaha jual beli; (c) menetapkan imbalan sehubungan dengan kegiatan usaha lainnya yang lazim dilakukan oleh bank dengan prinsip bagi hasil.

Dalam UU No. 7 Tahun 1992, kredit sebagai kegiatan yang dilakukan oleh bank konvensional diartikan lebih luas dari pengertian kredit yang diberikan pada UU No. 14 
Tahun 1967 tentang Pokok-pokok Perbankan (Barlinti, 2010:225). Pada Pasal 1 Huruf c, Undang-Undang Pokok-Pokok Perbankan Nomor 14 Tahun 1967 disebutkan definisi kredit adalah penyediaan uang atau tagihan-tagihan yang dapat disamakan dengan itu berdasarkan persetujuan pinjam-meminjam antar bank dengan lain pihak dalam mana pihak peminjam berkewajiban melunasi hutangnya setelah jangka waktu tertentu dengan jumlah bunga yang telah ditetapkan. Sementara pada Pasal 1 angka 12 UU No. 7 Tahun 1992 disebutkan definisi kredit, yaitu penyediaan uang atau tagihan yang dapat dipersamakan dengan itu, berdasarkan persetujuan atau kesepakatan pinjam meminjam antara bank dengan pihak lain yang mewajibkan pihak peminjam untuk melunasi hutangnya setelah jangka waktu tertentu dengan jumlah bunga, imbalan atau pembagian hasil keuntungan.

Pada UU No. 10 Tahun 1998 tentang Perubahan Atas UU No. 7 Tahun 1992 tentang Perbankan, istilah "bank berdasarkan prinsip bagi hasil" diubah dengan istilah "bank berdasarkan prinsip syariah". Disebutkan definisi prinsip syariah dalam Pasal 1 angka 13 adalah aturan perjanjian berdasarkan hukum Islam antara bank dan pihak lain untuk penyimpanan dana dan atau pembiayaan kegiatan usaha, atau kegiatan lainnya yang dinyatakan sesuai dengan syariah, antara lain, pembiayaan berdasarkan prinsip bagi hasil (mudärabah), pembiayaan berdasarkan prinsip penyertaan modal (mushärakah), prinsip jual beli barang dengan memperoleh keuntungan (murābaḥah), atau pembiayaan barang modal berdasarkan prinsip sewa murni tanpa pilihan (ijarah), atau dengan adanya pilihan pemindahan kepemiiikan atas barang yang disewa dari pihak bank oleh pihak lain (jiārah wa iqtinā').

Pada UU No. 10 Tahun 1998 pengertian kredit kembali kepada pengertian yang ada pada UU Pokok-Pokok Perbankan Nomor 14 Tahun 1967. Tahun Pengertian kredit itu sendiri dalam UU No. 10 Tahun 1998 telah mengeluarkan kata imbalan dan pembagian hasil keuntungan. Dalam pasal 1 angka 11 UU no 10 tahun 1998 disebutkan bahwa Kredit adalah penyediaan uang atau tagihan yang dapat dipersamakan dengan itu, berdasarkan persetujuan atau kesepakatan pinjam-meminjam antara bank dengan pihak lain yang mewajibkan pihak peminjam untuk melunasi utangnya setelah jangka waktu tertentu dengan pemberian bunga. Tanpa menyebut imbalan dan pembagian hasil. Penerapan imbalan dan pembagian hasil keuntungan termasuk dalam kegiatan pembiayaan. Bagi bank yang berdasarkan prinsip syariah tidak melaksanakan kegiatan kredit, tetapi melaksanakan kegiatan pembiayaan yang 
ljtihad, Jurnal Wacana Hukum Islam dan Kemanusiaan, Volume 13, No. 1, Juni 2013: 15-32

menerapkan imbalan atau bagi hasil sebagaimana terdapat dalam pasal 1 angka 12 UU No. 10 Tahun 1998.

Sepuluh tahun berikutnya (Barlinti, 2010:227), pemerintah mensahkan UU No. 21 Tahun 2008 yang khusus mengatur perbankan syariah. Istilah "bank berdasarkan prinsip syariah" diubah dengan istilah "bank syariah". Dua bentuk bank syariah disebut dengan Bank Umum Syariah (BUS) dan Bank Pembiayaan Rakyat Syariah (BPRS) merupakan bank-bank syariah yang melaksanakan kegiatan usahanya berdasarkan prinsip syariah. Pengertian prinsip syariah dalam UU No. 21 Tahun 2008 ini telah diubah dari pengertian yang diatur dalam UU No. 10 Tahun 1998, yaitu prinsip hukum Islam dalam kegiatan perbankan berdasarkan fatwa yang dikeluarkan oleh lembaga yang memiliki kewenangan dalam penetapan fatwa di bidang syariah. Pengertian pembiayaan juga mengalami perubahan dari ketentuan sebelumnya, dengan pengertian yang lebih luas lagi mencakup bentuk-bentuk transaksi yang dapat dilakukan dalam kegiatan pembiayaan tersebut baik dengan imbalan, tanpa imbalan, atau bagi hasil.

Bank Umum konvensional dapat mendirikan unit usaha syariah. Ketentuan mengenai Bank Umum yang melaksanakan kegiatan usaha berdasarkan prinsip syariah diatur dalam PBI No. 6/24/PBI/ 2004. Pada pelaksanaan kegiatan perbankan syariah, dengan dibentuknya DSN pada tahun 1999 dan penempatan DPS pada LKS, terdapat perubahan dalam ketentuanketentuan yang dibuat oleh BI. Dalam penyesuaian terhadap kegiatan perbankan syariah, dikeluarkan Surat Keputusan Direksi Bank Indonesia No. 32/34/KEP/DIR tanggal 12 Mei 1999 tentang Bank Umum Berdasarkan Prinsip Syariah. Kemudian pada tahun 2004, SK Direksi BI tersebut dicabut dengan PBI No. 6/24/PBI/2004 tentang Bank Umum Yang Melaksanakan Kegiatan Usaha Berdasarkan Prinsip Syariah. Dalam PBI ini diatur bahwa dalam setiap bank yang melaksanakan kegiatan usaha berdasarkan prinsip syariah wajib ditempatkan DPS yang memiliki tugas untuk mengawasi penerapan syariah dalam kegiatan usaha bank tersebut. Tugas, wewenang, dan tanggung jawab DPS antara lain memastikan dan mengawasi kesesuaian kegiatan operasional bank terhadap fatwa yang dikeluarkan oleh DSN, dan mengkaji produk dan jasa baru yang belum ada fatwa untuk dimintakan fatwa kepada DSN (Pasal 27 ayat (1) PBI No. 6/24/PBI/2004).

Hasil pengawasan yang dilakukan oleh DPS ini kemudian dilaporkan sekurang-kurangnya setiap 6 (enam) bulan kepada Direksi, Komisaris, DSN dan BI. Ketentuan lainnya adalah 
pada Pasal 38 PBI No. 6/24/ PBI/2004 ditentukan bahwa apabila bank ingin mengeluarkan produk dan jasa baru, bank wajib menyampaikan permohonan persetujuan atas produk dan jasa baru yang akan dikeluarkan kepada BI dengan wajib melampirkan fatwa DSN.

Berlakunya ketentuan PBI No. 9/19/PBI/2007 tentang Pelaksanaan Prinsip Syariah dalam Kegiatan Penghimpunan Dana dan Penyaluran Dana serta Pelayanan Jasa Bank Syariah pada tanggal 17 Desember 2007, maka ketentuan PBI No. 7 /46/PBI/2005 dicabut dan dinyatakan tidak berlaku lagi. Pada PBI No. 9/19/PBI/2007 Pasal 2 ayat (1) ditentukan bahwa bank syariah dalam melaksanakan kegiatan penghimpunan dana, penyaluran dana, dan pelayanan jasanya wajib memenuhi prinsip syariah. Prinsip syariah ini tercantum dalam Fatwa yang dikeluarkan oleh DSN. Pada Pasal 2 ayat (1) PBI No. 9/19/PBI/2007 ditegaskan bahwa: "Dalam melaksanakan kegiatan penghimpunan dana, penyaluran dana, dan pelayanan jasa, Bank wajib memenuhi Prinsip Syariah.” Penjelasan Pasal 2 ayat (1): "Prinsip Syariah yang wajib dipenuhi oleh Bank bersumber pada Fatwa yang dikeluarkan oleh Dewan Syariah Nasional."

Apabila ketentuan ini dilanggar maka bank syariah tersebut akan dikenakan sanksi administratif sebagaimana dimaksud dalam Pasal 52 ayat (2) UU No. 7 Tahun 1992 sebagaimana telah diubah dengan UU No. 10 Tahun 1998. Pada Pasal 5 PBI No.9/19/PBI/2007: "Bank yang tidak melaksanakan Prinsip Syariah sebagaimana dimaksud dalam Pasal 2 ayat (1) dikenakan sanksi administratif sebagaimana dimaksud dalam Pasal 52 ayat (2) UU No. 7 Tahun 1992 tentang Perbankan sebagaimana telah diubah dengan UU No. 10 Tahun 1998 berupa: a. teguran tertulis; b. penurunan tingkat kesehatan Bank; c. penggantian pengurus; dan/atau; d. pembekuan kegiatan usaha tertentu, baik untuk kantor cabang tertentu maupun untuk bank secara keseluruhan.

Puncak dari regulasi perbankan syariah pada akhirnya mengerucut pada pengesahan UU No. 21 Tahun 2008 tentang Perbankan Syariah pada tanggal 16 Juli 2008. Dalam menyelenggarakan kegiatan usaha perbankan syariah, bank syariah harus berpedoman pada prinsip syariah. Prinsip Syariah yang dimaksud oleh UU ini tertuang pada Pasal 1 angka 12 yaitu "prinsip hukum Islam dalam kegiatan perbankan berdasarkan fatwa yang dikeluarkan oleh lembaga yang memiliki kewenangan dalam penetapan fatwa di bidang syariah". Prinsipprinsip hukum Islam yang dijadikan dasar penyelenggaraan kegiatan perbankan syariah ini 
ljtihad, Jurnal Wacana Hukum Islam dan Kemanusiaan, Volume 13, No. 1, Juni 2013: 15-32

ditentukan bahwa terdapat dalam fatwa yang dibuat oleh lembaga yang berwenang. Mengenai lembaga yang berwenang menerbitkan fatwa, secara jelas dapat terlihat pada ketentuan Pasal 26.

Pada Pasal 26 UU No. 21 Tahun 2008 tentang Perbankan Syariah ditentukan bahwa Bank Umum Syariah (BUS), Unit Usaha Syariah (UUS), dan Bank Pembiayaan Rakyat Syariah (BPRS) dalam melaksanakan kegiatan usaha dan atau produk dan jasa syariahnya wajib tunduk kepada Prinsip Syariah sebagaimana yang difatwakan oleh MUI. Fatwa MUI ini dituangkan dalam Peraturan Bank Indonesia (PBI) yang disusun oleh Komite Perbankan Syariah di BI. Hal ini merupakan pengakuan bahwa MUI merupakan lembaga yang berwenang untuk menerbitkan fatwa yang dijadikan dasar dalam kegiatan usaha perbankan syariah. Pada pasal itu ditegaskan bahwa: Pertama, kegiatan usaha sebagaimana dimaksud dalam Pasal 19, Pasal 20, dan Pasal 21 dan/atau

produk dan jasa syariah, wajib tunduk kepada prinsip Syariah. Kedua, prinsip syariah sebagaimana dimaksud pada ayat (1) difatwakan oleh MUI. Ketiga fatwa sebagaimana dimaksud pada ayat (2) dituangkan dalam Peraturan Bank Indonesia. Keempat, dalam rangka penyusunan peraturan Bank Indonesia sebagaimana dimaksud pada ayat (3) Bank Indonesia mementuk komite perbankan syariah

Pada Penjelasan Umum UU tentang Perbankan syariah disebutkan bahwa "masalah kepatuhan syariah (syariah compliance) yang kewenangannya berada pada MUI yang direpresentasikan melalui Dewan Pengawas Syariah yang harus dibentuk pada masing-masing Bank Syariah dan UUS. Untuk menindaklanjuti implementasi fatwa yang dikeluarkan MUI ke dalam PBI, di dalam internal BI dibentuk komite perbankan syariah yang keanggotaannya terdiri atas perwakilan dari BI, Departemen Agama, dan unsur masyarakat yang komposisinya berimbang", dengan memiliki keahlian di bidang syariah dan berjumlah paling banyak 11 (sebelas) orang (Penjelasan Pasal 26 ayat (4).

Dalam ketentuan Pasal 55 mengenai penyelesaian perkara juga disebutkan bahwa dalam menyelesaikan perkara perbankan syariah yang dilakukan oleh lembaga penyelesaian perkara tidak boleh bertentangan dengan Prinsip Syariah. Oleh karena itu, hakim atau arbiter atau siapapun yang menyelesaikan perkara di bidang perbankan syariah ini harus menggunakan prinsip syariah ini, yaitu yang tertuang dalam fatwa MUI. Di dalam organisasi MUI, yang 
berwenang untuk membuat fatwa di bidang ekonomi syariah (termasuk perbankan syariah) adalah DSN, yang kemudian disebut dengan Fatwa DSN.

PBI No. 10/17/PBI/2008 tentang Produk Bank Syariah dan Unit Usaha Syariah menentukan bahwa dalam hal Bank Syariah dan UUS hendak mengeluarkan produk baru harus menyampaikan laporan rencana pengeluaran produk baru tersebut kepada BI. Apabila produk baru tersebut termasuk produk yang ditetapkan dalam Buku Kodifikasi Produk Perbankan Syariah (KPPS), maka BI akan memberikan penegasan tidak keberatan atas produk tersebut. Produk-produk yang ditetapkan dalam KPPS adalah giro, tabungan, deposito, pembiayaan atas dasar akad mudärabah, pembiayaan atas dasar akad mushärakah, pembiayaan atas dasar akad murābạ̣ah, pembiayaan atas dasar akad saläm, pembiayaan atas dasar akad istisbna', pembiayaan atas dasar akad ijärah, pembiayaan atas dasar akad qard, pembiayaan multijasa, L/C impor syariah, bank garansi syariah, dan penukaran valuta asing. Namun, apabila produk baru tersebut tidak termasuk produk yang ditetapkan dalam KPPS, maka Bank Syariah dan UUS wajib memperoleh persetujuan dari BI. Dalam KPPS berisikan fitur-fitur produk bank syariah baik dari sisi pendanaan (pasiva) maupun sisi pembiayaan (aktiva), serta informasi mengenai kemanfaatan, jenis akad, risiko, referensi peraturanperaturan BI, dan landasan-landasan hukum syariah berupa fatwa-fatwa yang dikeluarkan oleh DSN.

\section{Menjaga kepatuhan pada prinsip-prinsip syariah}

Sebagaimana disebutkan sebelumnya, otoritas yang mendapat wewenang untuk mengeluarkan fatwa keuangan syariah di Indonesia adalah Dewan Syariah Nasional Majelis Ulama Indonesia (DSN-MUI). Hal ini pertama kali diformulasikan secara legal-formal baru dalam Surat Keputusan Direksi Bank Indonesia tentang Bank Umum berdasarkan syariah (12 Mei 1999). Dalam pasal 1 (j) Surat Keputusan Direksi Bank Indonesia disebutkan bahwa: Dewan Syariah Nasional adalah dewan yang dibentuk oleh MUI yang bertugas dan memiliki wewenang untuk memastikan kesesuaian antara produk, jasa, dan kegiatan usaha bank dengan prinsip syariah. Pada ayat sama dijelaskan pula tentang Dewan Pengawas Syariah yang merupakan dewan yang bersifat independen dan dibentuk oleh Dewan Syariah Nasional (DSN), serta ditempatkan pada bank dengan tugas yang diatur oleh Dewan Syariah Nasional. 
ljtihad, Jurnal Wacana Hukum Islam dan Kemanusiaan, Volume 13, No. 1, Juni 2013: 15-32

Kemudian dalam Undang-Undang (UU) nomor 21 tahun 2008 tentang Perbankan Syariah, yang disahkan pada 16 Juli 2008, fungsi pengawasan terhadap kepatuhan syariah ini dinyatakan kembali, walaupun tidak menyebut DSN secara spesifik. UU tersebut menggariskan bahwa otoritas kepatuhan syariah berada pada MUI (MUI) yang direpresentasikan melalui Dewan Pengawas Syariah (DPS), yang harus dibentuk pada masing-masing Bank Syariah dan Unit Usaha Syariah (UUS) pada bank konvensional. Tugas perumusan dan pengawasan yang menjadi wewenang MUI berdasarkan UU Nomor 21 tahun 2008 inilah selanjutnya dilakukan oleh sebuah lembaga bentukan MUI yang disebut DSN. Dengan demikian, DSN tidak secara spesifik disebut dalam UU tapi merupakan komponen MUI yang berwenang melakukan perumusan dan pengawasan perbankan syariah.

Penjabaran otoritas DSN-MUI itu diwujudkan dalam dua hal (Karni, 2010:2). Pertama, otoritas perumusan prinsip syariah. MUI menjadi otoritas satu-satunya yang disebutkan UU, dengan fungsi membuat fatwa tentang prinsip syariah (Amin, 2008). Karena fatwa MUI bukan bagian sumber hukum dalam tata urutan peraturan perundang-undangan yang mengikat, (Asshiddiqie, 2006:110) maka agar berkekuatan operasional, fatwa itu dituangkan dalam wadah legal berupa Peraturan Bank Indonesia (PBI). Proses peralihan dari fatwa MUI menjadi PBI itu dikelola oleh Komite Perbankan Syariah (KPS), sebuah komite di internal BI. Kedua, tahap pengawasan. Mekanisme pengawasan kepatuhan syariah diwujudkan dalam bentuk penyediaan divisi kontrol internal berupa DPS di setiap bank syariah. Peran MUI adalah memberi rekomendasi calon anggota DPS sebelum ditetapkan oleh Rapat Umum Pemegang Saham (RUPS). DPS inilah yang merepresentasikan otoritas kepatuhan syariah dari MUI untuk diterapkan pada tiap bank syariah. DPS menjadi kepanjangan tangan MUI untuk memonitor implementasi fatwa MUI.

Secara umum, model otoritas kepatuhan yang demikian itu merupakan peneguhan praktek yang sudah berjalan sebelum UU 21/2008 lahir. MUI sudah lama memainkan peran penting dalam perjalanan perbankan syariah di Indonesia. Meskipun bukan badan hukum publik, bukan bagian lembaga negara, MUI pasca UU tersebut, diberi otoritas mengeluarkan ketentuan yang memberi kesan mengikat publik, sebagaimana layaknya badan hukum publik. Sebelum berlakunya UU Nomor 21 Tahun 2008, fatwa MUI dalam perumusan regulasi tidak mengikat (Karni, 2010:2). 
Sebelum berlakunya UU 21/2008, fatwa MUI sudah banyak yang diserap oleh regulator menjadi regulasi, tetapi formula penyerapannya tergantung kebijakan regulator. Ada fatwa yang diserap secara utuh, ada pula yang diserap secara parsial, dan ada juga yang diabaikan (Adams, 2000:326-331). Mekanisme penyerapan fatwa yang demikian itu, sejalan dengan hakekat dasar fatwa sebagai produk hukum Islam yang tidak mengikat. Otoritas regulasi tidak terikat mematuhi fatwa. Semenjak berlakunya UU Nomor 21 Tahun 2008 pasal 26, fatwa MUI dinyatakan menjadi rujukan resmi dalam penyusunan Peraturan BI tentang prinsip syariah di Indonesia.

Sejak berdirinya pada tahun 2000 hingga sekarang, DSN-MUI telah menerbitkan 82 fatwa, mengenai giro, tabungan, deposito, murabahah, jual beli salam, pembiayaan musyarakah, pembiayaan ijarah, wakalah, kafalah, hawalah, diskon dalam murabahah, pencadangan penghapusan aktiva produktif, investasi Reksadana Syariah, safe deposit box, rahn emas, rekening koran Syariah, obligasi Syariah, letter of credit, pasar modal Syariah, Syariah Charged card, sertifikat bank Indonesia Syariah ju'alah, hak memesan efek terlebih dahulu (HMETD) Syariah, Surat Berharga Syariah Negara, sale and lease back, dan lain-lain. Sebagian besar fatwa-fatwa DSN itu merupakan jawaban atas masalah-masalah perbankan Syariah (58 fatwa), sebagian lainnya tentang asuransi Syariah (6 fatwa), pasar modal Syariah (10 fatwa), pembiayaan Syariah (1 fatwa), pegadaian Syariah (3 fatwa), surat berharga Syariah Negara (3 fatwa), dan akuntansi Syariah (1 fatwa) (Muzhar, 2012:12).

Sebagian besar dari fatwa-fatwa DSN-MUI itu kemudian diadopsi oleh Bank Indonesia (BI) atau Kementerian Keuangan Republik Indonesia khususnya Direktorat Jenderal Lembaga Keuangan, Direktorat Jendral Pengelolaan Utang, dan Badan Pengawas Pasar Modal dan Lembaga Keuangan (Bapepam LK) menjadi peraturan perundangan yang mengikat. Bahkan sebagiannya diadopsi oleh Negara menjadi bagian dari Undang-undang. Yeni Salma Barlinti dalam disertasinya pada Fakultas Hukum Universitas Indonesia yang telah diterbitkan menjadi buku berjudul "Kedudukan Fatwa Dewan Syariah Nasional Dalam Sistem Hukum Nasional Indonesia" menyimpulkan bahwa peraturan-perundangan tentang perbankan Syariah, asuransi Syariah, pasar modal Syariah dan pembiayaan Syariah, memberikan kedudukan khusus kepada fatwa DSN-MUI. Kedudukan ini terlihat dalam isi pasal-pasal yang menyebutkan baik secara implisit maupun eksplisit atas fatwa DSN-MUI. 
ljtihad, Jurnal Wacana Hukum Islam dan Kemanusiaan, Volume 13, No. 1, Juni 2013: 15-32

Barlinti menyatakan bahwa kedudukan fatwa DSN dalam sistem perundang-undangan di Indonesia dapat dilihat pada empat komponen: 1. Fatwa DSN sebagai prinsip Syariah yang merupakan pedoman pelaksanaan kegiatan ekonomi Syariah yang harus ditaati; 2. fatwa DSN menjadi pedoman bagi DPS dalam mengawasi kegiatan usaha LKS; 3. isi ketentuan fatwa DSN diserap kedalam peraturan perundang-undangan; 4. fatwa DSN menjadi landasan hukum bagi LKS dalam menjalankan produk kegiatan usahanya (Barlinti, 2010; 556).

Temuan Yeni Salma Barlinti diantaranya mendapati bahwa isi Peraturan Bank Indonesia (PBI) No. 7/46/PBI/2005 Pasal 3, 4, dan 5, sama isinya dengan fatwa DSN-MUI No. 1/ DSN-MUI/IV/2000 Tentang Giro, fatwa DSN No. 2/DSN-MUI/IV/2000 Tentang Tabungan, dan fatwa DSN No. 3/DSN-MUI/IV/2000 Tentang Deposito. Selanjutnya Pasal 6 dan 7 PBI No. 7/46/PBI/2005 sama isinya dengan fatwa DSN-MUI No. 7/ DSN-MUI/14/2000 Tentang Pembiayaan Mudharabah (Qiradh) dan fatwa DSN No. 15/DSN-MUI/IX/2000 Tentang Prinsip Distribusi Hasil Usaha Dalam Lembaga Keuangan Syariah. Kemudian Pasal 8 PBI No.7/46/PBI/2005 sama isinya dengan fatwa DSN No. 8/DSN-MUI/IV/2000 Tentang Pembiayaan Musyarakah. Selanjutnya Pasal 13 dan 14 PBI No. 7/46/2005 paralel isinya dengan fatwa DSN No. 5/DSN-MUI/IV/2000 Tentang Jual Beli Salam, fatwa DSN No. 6/DSN-UI/IV/2000 Tentang Jual Beli Istishna', dan fatwa DSN No. 22/DSN-MUI/III/2002 Tentang Jual Beli Istishna’ Paralel.

Proses pengadopsian fatwa ke dalam regulasi perbankan tentunya bukan sesuatu yang "ujug-ujug" melainkan memerlukan sosialisasi, pendekatan dan lobi-lobi. Dalam kasus PBI No. 7/46/PBI/2005 itu, Bank Indonesia memerlukan waktu lima tahun untuk mencerap sejumlah fatwa DSN-MUI ( Muzhar, 2012:14).

Sampai dengan bulan Juni tahun 2011, sedikitnya terdapat 43 fatwa DSN-MUI yang paling banyak diacu dan dijadikan dasar operasional industri perbankan Syariah di Indonesia. Sejumlah Surat Edaran dan PBI lainnya juga telah dipengaruhi oleh fatwa-fatwa DSN, seperti PBI No.4/1/PBI/2004, PBI No. 6/24/PBI/2004, PBI No. 9/19/PBI/2007, PBI No. 10/11/PBI/2008, Surat Edaran Bank Indonesia No. 8/19/Dpbs tanggal 24 Agustus 2006, Surat Edaran Bank Indonesia No. 10/14/Dpbs tanggal 17 Maret 2008, dan lain-lain. Sejak 2002, Bank Indonesia juga telah memiliki sebuah biro dan kemudian berubah menjadi direktorat yang khusus menangani masalah-masalah perbankan Syariah. 
Badan Pengawas Pasar Modal dan Lembaga Keuangan Kementerian Keuangan (Bapepam LK Kemenkeu) juga telah mengadopsi sejumlah fatwa DSN-MUI untuk dijadikan dasar regulasi bisnis asuransi Syariah, pasar modal Syariah, pegadaian Syariah, dan pembiayaan Syariah. Sebagian fatwa itu adalah fatwa yang sama dengan yang telah diadopsi Bank Indonesia, dan sebagian fatwa lainnya bersifat khusus. Dalam "Siaran Pers Akhir Tahun" yang dikeluarkan pada tanggal 28 Desember 2006, BAPEPAM-LK mengakui bahwa sejalan dengan prioritas sasaran dan target yang telah ditetapkan, Ketua Bapepam-LK pada tanggal 23 November 2006 telah mengeluarkan Keputusan Bapepam-LK No. Kep-130/BL/2006 dan No. Kep-131/BL/2006 yang merupakan paket regulasi terkait penerapan prinsip Syariah di Pasar Modal (Peraturan Nomor IX.A.13 dan Nomor IX.A.14) dan penyusunannya telah melibatkan secara aktif Dewan Syariah Nasional - Majlis Ulama Indonesia, sehingga hasilnya diklaim selaras dengan prinsip Syariah dan fatwa-fatwa DSN-MUI. Kemudian terhadap paket regulasi tersebut DSN-MUI, melalui suratnya No. B-271/DSN-MUI/XI/2006 tanggal 24 November 2006, menyatakan bahwa peraturarn-peraturan tersebut secara umum tidak bertentangan dengan prinsip Syariah dan fatwa-fatwa yang telah dikeluarkan oleh DSNMUI. Adapun untuk keperluan operasional industri asuransi Syariah, KH.Ma'ruf Amin mengatakan bahwa fatwa-fatwa yang dijadikan pedoman ialah fatwa DSN-MUI No. 21/ DSN-MUI/X/2001 Tentang Pedoman Umum Asuransi Syariah, fatwa No. 39/DSNMUI/X/2002 Tentang Asuransi Haji, fatwa No. 51/DSN-MUI/III/2006 Tentang Akad Mudharabah Musytarakah Pada Asuransi Syariah, fatwa No. 52/DSN-MUI/III/2006 Tentang Akad Wakalah Bil Ujrah Pada Asuransi dan Reasuransi Syariah, dan fatwa No. 53/ DSN-MUI/III/2006 Tentang Akad Tabarru’ pada Asuransi dan Reasuransi Syariah.

Pernyataam K.H. Ma'ruf Amin tersebut dikonfirmasi oleh temua penelitian Yeni Barlinti bahwa banyak peraturan di bidang asuransi Syariah yang telah mengadopsi fatwa DSNMUI, salah satunya ialah Peraturan Menteri Keuangan (PMK) No. 18/PMK.010/2010 Tentang Penerapan Prinsip Dasar Penyelenggaraan Usaha Asuransi dan Usaha Reasuransi dengan Prinsip Syariah yang dalam konsideran butir a PMK itu menyebutkan secara ekplisit keharusan senantiasa memenuhi prinsip Syariah Islam, termasuk fatwa-fatwa yang ditetapkan oleh Dewan Syariah Nasional -Majlis Ulama Indonesia. Setelah membandingkan secara seksama isi pasal-pasal PMK itu dengan isi sejumlah fatwa DSN-MUI, Barlinti menemukan 
ljtihad, Jurnal Wacana Hukum Islam dan Kemanusiaan, Volume 13, No. 1, Juni 2013: 15-32

bahwa Pasal 1, 7, 8, 9, 10, 11, 12 dan 15 PMK itu sama isinya dengan fatwa-fatwa DSNMUI No. 7/DSN-MUI/IV/2000, No. 21/DSN-MUI/X/2001, No. 50/DSN-MUI/ III/2006, No. 51/DSN-MUI/III/2006, No. 52/DSN-MUI/III/2006, dan No. 53/DSNMUI/III/2006.

Dalam rangkaian yang lebih luas, fatwa DSN-MUI juga mewarnai dua undang-undang yang terkait ekonomi syariah yaitu UU No. 19 Tahun 2008 Tentang Surat Berharga Syariah Negara (SBSN) dan UU No. 21 Tahun 2008 Tentang Perbankan Syariah. Dalam UU No. 19 Tahun 2008 Tentang SBSN, pentingnya peran fatwa DSN-MUI diatur dalam Pasal 25 yang mengatakan bahwa dalam rangka penerbitan SBSN, Menteri Keuangan meminta fatwa atau pernyataan kesesuaian SBSN terhadap prinsip-prinsip Syariah dari lembaga yang memiliki kewenangan dalam penetapan fatwa di bidang Syariah. Kemudian dalam Penjelasan Pasal itu dikatakan bahwa lembaga yang memiliki kewenangan dalam menetapkan fatwa di bidang Syariah adalah MUI atau lembaga lain yang ditunjuk Pemerintah. Dengan demikian fatwa yang dimaksud adalah adalah fatwa DSN-MUI, karena hanya DSN-MUI yang mengeluarkan fatwa di bidang ekonomi.

Pengadopsian fatwa ke dalam peraturan perundang-undangan tiada lain merupakan proses taqnin (positivisasi hukum). Fatwa yang tadinya tidak mengikat dan hanya bersifat normatif bertransformasi menjadi peraturan perundang-undangan yang mengikat. Pelanggaran terhadap peraturan perundang-undangan ini dapat mengakibatkan pelakunya dijatuhi sanksi. Seperti ditegaskan dalam pasal 64 UU Perbankan Syariah No 21 Tahun 2008 bahwa pihak terafiliasi yang dengan sengaja tidak melaksanakan langkah-langkah yang diperlukan untuk memastikan ketaatan Bank Syariah atau Bank Umum Konvensional yang memiliki UUS dapat dipidana 3 tahun sampai 8 tahun atau denda 5- 100 milyar. Pada pasal 65 jika pelanggaran dilakukan oleh pemegang saham yang menyuruh komisaris, direksi, atau pegawai bank syariah melakukan langkah-langkah yang melanggar ketaatan bank termasuk termasuk ketaatan syariah (sharia compliance), maka dapat dijatuhi pidana penjara715 tahun atau denda 10-200 milyar (Amin, 2012: 7-8) Hal ini tentunya termasuk jika melanggar pasal 24 angka (1) huruf a, yang menegaskan bahwa Bank Syariah dilarang melakukan kegiatan usaha yang bertentangan dengan prinsip syariah. 
Secara subtansial peraturan perundang-undangan yang berkaitan dengan perbankan syariah sudah berada pada jalur syar'i. Setidaknya menurut pemahaman para ulama otoritatif yang berhimpun dalam Dewan Syariah Nasional. Walaupun boleh jadi hal berbeda dapat terjadi dalam implementasi di lapangan. Misalnya dalam produk dana talangan haji. Dalam Fatwa DSN No. 29/DSN-MUI/VI/2002 tentang Pembiayaan Pengurusan Haji Lembaga Keuangan Syariah. LKS dapat menalangi pembayaran BPIH dengan menggunakan prinsip Qardh yang digabung dengan ijarah. Namun ujrah (fee) jasa pengurusan haji tidak boleh dipersyaratkan dengan pemberian talangan haji dan besaran wirab tidak boleh didasarkan pada jumlah talangan qard. Namun faktanya di lapangan, semakin besar dana dan semakin lama dana talangan semakin besar pula jumlah ujrah yang harus dibayarkan. Kemudian contoh yang lain fatwa DSN Nomor 26/DSN-MUI/III/2002 tentang Rahn Emas dihubungkan dengan fatwa No 77/DSN-MUI/V/2010 tentang Jual-Beli Emas Secara Tidak Tunai. Produk gadai dan jual beli pada dasarnya dilakukan untuk kegiatan mendesak dan berbasis pada jaminan barang yang riil. Namun faktanya di lapangan produk ini telah menjadi produk derivatif yang menjauh hakikat dan tujuan dibolehkannya gadai. Namun, sebelum terjadi hal yang lebih jauh BI telah mengeluarkan Surat Edaran No.14/16/Dpbs perihal Produk Pembiayaan Kepemilikan Emas bagi Bank Syariah dan Unit Usaha Syariah. Atas dasar kehati-hatian, maka pembiayaan kepemilikan emas (PKE) dibatasi paling besar 150 juta per nasabah, jika PKE digabung dengan qardberagun emas maka jumlah pembiayaan maksimal 250 juta dengan jangka waktu 2-5 tahun.

\section{Penutup}

Salah seorang tokoh ekonomi Syariah Syafi'i Antonio menegaskan bahwa berkaitan dengan perkembangan keuangan syariah, Indonesia telah memiliki infrastruktur legal yang memadai. Dari sisi regulasi, Pemerintah telah cukup memberi dukungan. Namun dari sisi keberpihakan dan afirmative policy kepada LKS masih sangat kurang. Di antara bentuk tiadanya dukungan pemerintah adalah pemerintah belum menunjukan tanda-tanda akan menunjuk bank-bank syariah syariah secara eksklusif untuk menjadi bank penerima Biaya Perjalanan Ibadah Haji (BPIH). Padahal potensi pendanaan cukup besar. Sampai Februari 2010 saja dana terkumpul dari setoran awal BPIH adalah Rp 32 triliun. 
ljtihad, Jurnal Wacana Hukum Islam dan Kemanusiaan, Volume 13, No. 1, Juni 2013: 15-32

Untuk sekedar pembanding, di Malaysia jumlah aset perbankan syariahnya telah mencapai 123 miliar dolar AS (hampir Rp 1100 triliun). Angka ini hampir sepuluh kali lipat total aset perbankan syariah nasional yang hanya 155,4 triliun. Jika dibandingkan dengan total aset perbankan secara keseluruhan, maka total aset perbankan syariah Malaysia sudah mencapai angka 21 persen sementara Indonesia hanya 3,99 persen.

Salah satu kunci keberhasilan Malaysia dalam mendorong pengembangan ekonomi syariah terletak pada dukungan kebijakan yang sangat kuat, di samping proses edukasi publik yang bersifat kontinyu. Secara garis besar, master plan untuk kemajuan sektor keuangan dan pasar modal Malaysia dapat dibagi menjadi tiga tahapan utama. Pertama, pengembangan infrastruktur keuangan. Kedua, peningkatan kapasitas dan kemampuan lembaga-lembaga keuangan. Ketiga, pengembangan regulasi-regulasi yang mendukung iklim kompetisi yang sehat. Bukti nyata dari keberpihakan itu adalah pemerintah juga menempatkan dananya di bank syariah yang sudah ada. Menurut data resmi yang dirilis Kementerian Keuangan Malaysia, sekitar 53 persen dana APBN Malaysia ditempatkan di bank syariah. Belum lagi ditambah dengan penempatan dana BUMN Malaysia di bank-bank syariah negeri jiran tersebut (www.hidayatullah.com, 2012).

Karena itu, mengembangkan lembaga ekonomi syariah di Indonesia dan menjaganya tetap murni syariah merupakan lahan jihad bagi para semua pihak yang memiliki perhatian bagi pengembangan lembaga keuangan syariah. Jihad dalam pengertian mengerahkan seluruh daya upaya untuk mencapai kemaslahatan yang akan dirasakan oleh sebanyak mungkin umat manusia. Ekonomi syariah bukan hanya milik umat Islam, tetapi milik mereka yang menginginkan tatanan lebih baik dalam peradaban umat manusia.

\section{Daftar pustaka}

Adams, Wahidudin. Pola Penyerapan Fatwa Majelis Ulama Indonesia dalam Peraturan PerundangUndangan 1975-1977. Disertasi: UIN Jakarta, 2000.

Amin, Ma'ruf . Fatwa Dalam Sistem Hukum Islam. Jakarta: elSAS, 2008.

Amin, K.H. Ma'ruf. Pembaruan bukum ekonomi Syariab dalam Pengembangan Produk Kenangan Kontemporer (Transformasi Fikih Muamalah dalam Pengembangan Ekonomi Syariah). Jakarta: Pidato Ilmiah pada penganugerahan Gelar Doktor Kehormatan K.H. Ma'ruf Amin, 2012. 
Ariff, Mohammed. "Islamic Banking in Southeast Asia" dalam Howard M. Federspiel (Ed.), An Anthology Of Islamic Studies Vol. III. Canada: McGill Institute of Islamic Studies, 1996.

Asshiddiqie, Jimly dan Ali Safaat, Teori Hans Kelsen Tentang Hukum. Jakarta: Setjen \& Kepaniteraan MK-RI, 2006.

Barlinti, Yeni Salma. Kedudukan Fatwa Dewan Syariah Nasional dalam Sistem Hukum Nasional di Indonesia. Jakarta: Badan Litbang Dan Diklat Kementrian Agama RI ,2010.

Departemen Penelitian dan Pengaturan Perbankan Grup Stabilitas Sistem Keuangan Bank Indonesia. Kajian Stabilitas Keuangan. No. 19 September 2012.

Freeman, M.D.A. Lloyd's Introduction to Jurisprudence. London: Sweet \& Maxwell. Ltd., 1994.

Friedmann, W. Teori dan Filsafat Hukum, Idealisme Filosofis dan Problema Keadilan. Jakarta: Rajawali, 1990.

Karim, Adiwarman A. “Economic Outlook 2012,” Republika, Senin 10 Oktober 2011.

Karni, Asrori S. Problem Konseptual Otoritas Kepatuhan Syariah (Shariah Compliance) dalam Regulasi Perbankan Syariah. Tesis: UI, 2010.

Keputusan Ketua Bapepam dan LK Nomor Kep-261/BL/2011 tentang Daftar Efek Syariah berjumlah 225. Kemudian disusul dengan Keputusan Ketua Bapepem dan LK Nomor Kep-377/BL/2011.

Mudzhar, M. Atho. K.H. Ma'ruf Amin: Seorang Ulama yang Cemerlang dalam Ilmu Hukum Ekonomi Syariah dan Motor Penggerak Ekonomi Syariah di Indonesia. Jakarta: Pidato Promotor I Anugerah Doctor Honoris Causa K.H. Ma'ruf Amin, 2012.

Muhamad, Lembaga-Lembaga Keuangan Umat Kontemporer (Yogyakarta: UII Press, 2000), 62. Peraturan BI nomor 32/10/PBI/2008 tentang Komite Perbankan Syariah.

Peraturan BI nomor 11/3/PBI/2009 tentang Bank Umum Syariah.

Republika, Bank Syariah Tetap Menarik, 9 Januari 2012.

Undang-Undang tentang Perbankan Syariah, UU No. 21 Tahun. 2008.

\section{Internet:}

http:/ /www.bi.go.id/NR/rdonlyres/6C1B0572-0593-4A20-B053-4D8F386267D0/ 17640/Perkembangan_Impresif_iB_Perbankan_Syariah.pdf (diakses 12 November 2010).

http://www.bi.go.id/ Statistik Perbankkan syariah Bulan April 2010 (diakses 11 November 2010). 
ljtihad, Jurnal Wacana Hukum Islam dan Kemanusiaan, Volume 13, No. 1, Juni 2013: 15-32

http://www.bi.go.id/ Statistik Perbankkan syariah Bulan April 2010 (diakses 11 November 2010).

http:/ / www.bi.go.id/ Statistik Perbankkan syariah Bulan November 2011 (diakses 9 Januari 2012).

http://www.hukumonline.com/berita/baca/lt4fe072d6b1052/regulasi-industri-syariahnasional-cukup-memadai (diakses 25 November 2012)

http://nasional.vivanews.com/news/read/290110-alasan-kpk-usul-moratoriumpendaftaran-haji (diakses 9 Maret 2012)

http://majalah.hidayatullah.com/?p=3087. Irfan Syauqi Bek, Mengembangkan Ekonomi Syariab: Pelajaran dari Malaysia (diakses 25 November 2012) 